International Journal of Child, Youth and Family Studies (2013) 3.1: 433-443

\title{
FORGING ETHICAL ADULT-YOUTH RELATIONSHIPS WITHIN EMANCIPATORY ACTIVISM
}

\section{Rachel E. Evans and Darren E. Lund}

\begin{abstract}
The authors engage in a duoethnographic dialogue about their past work as activists in a high school setting, where Rachel was a high school student and Darren a teacher-advisor. Their discussion focuses on their recollections of the formation of a Gay-Straight Alliance (GSA) within a conservative community setting, the first of its kind in the Province of Alberta. Reflecting critically on their own roles, they explore the dimensions of effective adult-youth collaborations, including notions of power and privilege, and the role of adults in protecting students from hostile community backlash. Using specific illustrations, the authors outline some of the optimal qualities of adult-youth projects in a way that can enable and empower young people, while avoiding unduly burdening them with the responsibility to solve all social inequity.
\end{abstract}

Keywords: student activism, gay-straight alliances, adult-youth collaboration, social justice, duoethnography

Rachel E. Evans, BFA, is a Humane Education Coordinator with the SPCA in Victoria, British Columbia. She is accepted to a City Planning Master's program at the University of Manitoba. E-mail: 26sharks@gmail.com

Darren E. Lund, Ph.D. is a Professor in the Faculty of Education at the University of Calgary, 2500 University Drive NW, Calgary, Alberta, Canada, T2N 1N4. Telephone (403) 220-7365. E-mail: dlund@ucalgary.ca 
International Journal of Child, Youth and Family Studies (2013) 3.1: 433-443

Rachel: Hey Darren, now that a bit of time has passed, I am wondering what your thoughts have been on the "Transforming Practices: Emancipatory Approaches to Youth Engagement” conference held in Montreal in June 2012, in relation to your ongoing work with youth activists. It was such a wonderful gathering of young people and scholars, all focused on how best to engage in activist work in respectful and collaborative ways. Have you been able to put some of the things you learned or realized into action?

Darren: Thanks for contacting me again, Rachel. Yes, it has been a few months now, and I am often reminded of our experiences at that excellent meeting. I especially appreciated the collegial and interactive nature of the sessions. It did not feel like a typical conference at all, but more of a gathering of like-minded colleagues to have an indepth conversation about a specific topic, in this case, adult-youth collaborations on social activism. For me, it was exciting to attend with Maryam Nabavi, a colleague with whom I've written about youth activism in the past (e.g., Nabavi \& Lund, 2010), and who was attending with her own youth activist colleague.

Your question is important, as it stimulates me to reflect more deeply on how we each move forward after an inspirational meeting to make some tangible progress on our work. In my case, I'm fortunate in that I have two current research projects regarding youth and social justice that both benefit from these insights. One project is a three-year study on "Engaging Young People in Social Justice Research" funded by the Social Sciences and Humanities Research Council of Canada and the other is a community-led project that engages pre-service teachers in service-learning opportunities with children and youth from immigrant families in our community (see Lund, Lee, Kaipainen, \& Bragg, 2012). Too often, young people in our communities are merely viewed as another niche market to be exploited as potential consumers (Boyles, 2008), or are demonized in the media as a lost generation, falsely stereotyped as either dangerous or apathetic. As Henry Giroux (2003) wrote, "if not represented as a symbol of fashion or hailed as a hot niche, youth are often portrayed as a problem, a danger to adult society or, even worse, irrelevant to the future" (p. xiv). An issue that we talked about in Montreal that continues to guide my current thinking is studying how to establish a healthy role as an adult mentor when working with youth. It almost seems like an art form to try to "do it right" and I remember one of my colleagues describing it as a kind of "syncopated rhythm" that emerges between students and teachers (SooHoo, 1995). I would love to hear your insights on this issue.

Rachel: Yes, I also felt it was an atypical conference in many ways. It was very conversational in nature, sort of like a ... duoethnographic conversation. I like that this piece respects each of our voices as distinct, which is really symbolic of the separate perspectives that adults and youth working together must honour. As you know, this new research methodology pioneered and named duoethnography by Joe Norris and Rick Sawyer features dialogic inquiry toward shared understandings that are only possible through a critical engagement across differences (Norris, Sawyer, \& Lund, 2012). When applied to youth-adult relationships, this methodology affords a more level playing field, as both participants become co-researchers. The differences in age and perspective add to the richness of the discussion, and allow for a more complex and ambiguous power 
International Journal of Child, Youth and Family Studies (2013) 3.1: 433-443

relationship than a typical student/adult dichotomy.

In a related vein, what I valued most at the Montreal conference was having the opportunity to speak with people in other communities about their work. It was so interesting to see such a diversity of people and initiatives come together, and to find similarities in terms of the challenges and realizations we all faced. Many of the participants emphasized the need for initiatives that are led by youth. In that sense, the adult in such a partnership is truly a mentor and role model. The position is to inspire and support rather than control. So I agree; that makes it a bit of an art form, and one that requires a fair amount of sensitivity and open communication.

Darren: You make a good point about inspiring and supporting versus the adult control model. Can you think of any specific examples where you have seen situations with inspiring and supportive adults? Any times where this wasn't the case? In our last duoethnographic conversation we reflected specifically on the challenges of starting a school-based activist club in the late 1990s that focused on Lesbian / Gay / Bisexual / Transsexual / Transgender (LGBTT) issues. As it turns out, our written conversation also became the first-ever published duoethnography (see Lund \& Evans, 2006). I am still learning the various forms this method can take, and am very impressed with how it builds on critical ethnography and autoethnography to allow deeper understandings through dialogue. As we discussed, our Gay-Straight Alliance was quite innovative and groundbreaking for its time. Having been initiated back in the 1999-2000 school year, it was the first such group in Alberta (Lund, 2007). In that conversation we focused a lot on our own identities and personal histories around sexual orientation and gender, working toward some new shared understandings. I'm wondering how your thinking has progressed in the five or six years since then?

Rachel: I still think our original Students and Teachers Opposing Prejudice (STOP) program that you helped form at Lindsay Thurber Comprehensive High School in Red Deer, Alberta, back in the mid-1980s would be the most obvious example of a supportive adult mentoring model. In particular with our formation of the Gay-Straight Alliance (GSA), some friends and I had the initial idea to organize it, but when you're 16 years old, you simply don't have the tools or the knowledge to see through an idea like that. Particularly with LGBTT youth, you may not have the confidence either. Even simply navigating the bureaucracy of the school administration could be enough of a challenge to put off many kids. I found it helpful to have you supporting us and using your experience with STOP to help us create this other group.

Darren: I actually remember being a bit afraid when you and your friend Rene came to me and asked if you could form the group. It really hadn't been done before in this province, and only a few times across Canada at that time, so we didn't have a proper model to use, and besides, we were living in a very conservative small prairie city. I am reminded of Paulo Freire's (1998) insistence that adults need to respect and attend to the lived experiences of students, and their calls for change. He insists that educators “establish an 'intimate' connection between knowledge considered basic to any school curriculum and knowledge that is the fruit of the lived experience of these students as 
International Journal of Child, Youth and Family Studies (2013) 3.1: 433-443

individuals” (p. 36). I'll admit that when you asked for my help to fight the homophobia in our school, I was personally very uncomfortable addressing these issues because I was tied to the notion that it was somehow a "teen sexuality" issue.

You two reminded me that it was really about creating a safe learning environment. This proactive approach in schools is now widely regarded as the morally, ethically, and pedagogically correct thing to do - and indeed there is much formal support for teachers and students wishing to form Gay-Straight Alliances in this province (Alberta Teachers' Association, 2012) - but at the time, it was all new territory. Now, there are handbooks, workshops, summer camps, and Facebook support groups to guide the formation of Gay-Straight Alliances, and there are currently dozens of such groups in the Province of Alberta alone. Your groundwork in convincing the school principal to consider it, and winning over the staff in a courageous talk to them about making the school a safe place, were both really remarkable accomplishments.

Rachel: Thank you. There was definitely a feeling that we were breaking new ground with the GSA. I think all of us felt afraid at some point, since we really didn't know what kind of reaction to expect. It's interesting that you would bring up the fact that you felt uncomfortable about the school administration or the public regarding the club as a teen sexuality issue. From my vantage point now, it strikes me as odd that dealing with a teen sexuality issue would have been an issue that we had to worry about at all! I mean the right to an inclusive education regarding sexuality and sexual health is also a basic human and moral right. People's discomfort regarding the spectrum of human sexuality is what has kept gay rights on the margin of human rights debates for so many years. When we started the GSA that was where our outrage was coming from. We were saying: "Why aren't we talking about this? Why are LGBTT people and their issues being swept under the rug when it comes to these important debates?" We were indignant about the fact that adults around us were asking us to confront human rights issues like racism and sexism, while effectively ignoring homophobia because it might mean they would have to mention sex. It was uncomfortable at the time, and risky. However, we all felt that it was a conversation that needed to be started, and we needed some adults to assist us.

Darren: Could you remind me of the point you raised at the conference about an adult mentor/sponsor needing to "protect" the young activists? That was an interesting point, but I see it as problematic in a way, since it implies a kind of paternalistic notion in my case, that these helpless kids need a mother hen or a father figure to shield them from the harsh realities of the world. Could you explain that point a bit?

Rachel: I know protection is a word that tends to make many activists bristle. The focus of this kind of activism is so much more about empowerment, but I think it's important for adult mentors to assume a somewhat protective role at times. We have to remember that the climate in Red Deer at that time was very homophobic, I would argue, and there were real threats that we could have faced after forming the group. Some of the young people involved in our group were being bullied and threatened daily. Even though we became empowered students through the formation of the group, we were still 
International Journal of Child, Youth and Family Studies (2013) 3.1: 433-443

vulnerable simply because we were young. It felt important to have adults on our side, on whom we could rely if and when the backlash came.

At that age, I don't recall having very clear knowledge about what my rights as a young person and student actually were, so I don't know that I could have been relied upon to defend them myself. This is where the protective element comes in and the importance of creating a safe space. The group really became about young people learning how to recognize and defend their rights. I also felt that we began to protect and stand up for each other. There was a sense of empowerment in that respect as well, but it developed over time. To me that was key. We were just learning, and I felt protected by the knowledge and access to the "adult world" that you had. None of the students had access to that, would you agree?

Darren: Certainly. I remember how uncomfortable many people were about our forming the group - including me, of course - and particularly our principal who knew that the community could easily critique this effort as "promoting a lifestyle" or some such nonsense. I was feeling confident as an "openly” straight person, married to a woman, that I would be understood to be an ally to LGBTT persons, but I also remember the other teacher-mentor, Kirsten Spackman, half-joking about on how this affiliation might ruin her opportunity to get dates with men in a small community! Moving forward with formally initiating the GSA group, we all decided that the alliance would be most comfortably located within the STOP program. Even though our meetings were held on a different weekday than the STOP meetings, the group was under the umbrella of an award-winning ${ }^{1}$ student activist program that had been around for over a decade, and that had brought our school and school district some national acclaim.

Rachel: Yes, I think it may have affected my ability to get dates, too! But joking aside, I think it is important to acknowledge that, like it or not, you were in a position of greater power than we were, by virtue of the fact that you were straight, white, male, an adult, and a teacher. I thought and still think it was very admirable to use that position to help us gain resources we wouldn't otherwise have access to. So maybe ally feels like a more comfortable word than protector, but I do feel that there needs to be an element of responsibility or protection when adults are working with youth. I don't think we were helpless, but I do think we needed help.

Darren: I really appreciate the way you've expressed that. Now that my children are both around their teenage years now, I can appreciate how much trust we parents

\footnotetext{
${ }^{1}$ The STOP group won a number of local and national awards, including a 1989 Together We're Better Award from Canadian Heritage, a 1993 Canadian Student Human Rights Award from the League for Human Rights of B’Nai Brith, a 1998 Race Relations Award (with Darren Lund) from the Federation of Canadian Municipalities, a 1999 Harmony Award of Distinction (with Darren Lund) from the Harmony Movement, the March 2000 Freedom Fighter of the Month designation from the rock group, Rage Against the Machine, and a 2001 Award of Distinction from the Canadian Race Relations Foundation.
} 
must put in teachers on a daily basis. Of course, teachers also hold a legal role, through the concept of in loco parentis, as acting parents during the hours that young people are in school. When dealing with supervising and participating in social justice activism, the stakes are even higher. If you think about it, the issues we're tackling together - race, gender, sexual orientation, ethnicity, language, ability, age, religion, and the like - are hot-button topics that often elicit very emotional responses from people. These are also highly-charged political activities, and our dealing with them proactively within a public institution, even through a volunteer school club, puts us all on some rocky ground. You make a good point about the adults stepping up to take appropriate responsibility for the group. I can think of a number of moments in the GSA when students needed a kind of protection from school staff and community backlash. When we had just formed the GSA, one of my openly anti-gay colleagues sent a note to the school's staff e-mail list saying, "What's with all the gay stuff at school these days?" and I politely reminded him of his professional obligation to treat all students with dignity and respect (see Alberta Teachers’ Association, 1992).

Rachel: I don't remember hearing anything negative from teachers during those first few months after forming the GSA. In fact, I think we actually felt supported by most of the staff in the school, and I remember their positive reactions to our talk at that staff meeting where we first raised the idea of starting a GSA. I do remember that terrible incident that took place in Red Deer where a young man was beaten up for being gay. I also remember some media controversy over the group and ongoing letters to the editor of the local newspaper, many of which were hateful.

Darren: Yes, that assault was a horrifying incident. I was in my last month of teaching high school, when a local youth pastor wrote a letter to the editor of our local daily newspaper criticizing anyone who defended the rights of gay people as "perverse, self-centred, and morally deprived individuals" and “just as immoral as the pedophiles, drug dealers and pimps that plague our communities” (Boissoin, 2002, p. A4). Just two weeks later, a young gay man was beaten up in Red Deer by some other young men. They taunted him and asked him, "You're a faggot, right?" and then began beating him, crushing his right cheekbone and knocking out some of his teeth (Zielinski, 2002). The victim said to the newspaper reporter that he didn't “feel safe reading the anti-gay statements like the ones in the Red Deer Advocate's June 17 letter to the editor from Stephen Boissoin.” He continued, "I feel the letter was just encouragement for people to go out and stop the gay rights movement” (p. A2).

Rachel: That incident and the initial homophobic letter really reminded the whole community that homophobia was alive and well in our community, and that the health and safety of gay kids really were at risk. I was proud of you for actually filing that human rights complaint against Boissoin, and so pleased when you won at the Human Rights Panel tribunal almost five years later. It was disappointing that you later lost the ruling on appeal (Slade, 2012).

Darren: Yes, the upshot of that decade-long ordeal was quite disappointing, but it did open an important and ongoing national debate about hate speech and seeking 
International Journal of Child, Youth and Family Studies (2013) 3.1: 433-443

reasonable limits on free speech. I experienced a great deal of backlash as well, and even now continue to get hate mail and occasional death threats that the police investigate. Homophobia and hate are very real to me.

However, I have some serious reservations about loading students up with all the responsibilities of repairing the world. It is quite unfair of the adults in the community to say to young people that they are now the leaders in making improvements to social justice activism (and ironically, I've said and written about this topic many times myself). Really, this off-loading of the remedy to social ills onto the backs of young people is rather unethical, and I have recently written about it, both in an encyclopedia entry on student activism (Lund, 2012), and in a rather self-critical dialogue on this issue (Lund \& Paul, 2011). My main critique is that, too often, adults abdicate our own responsibility for remedying inequity and injustice by concluding that youth must take the lead since we have failed. It is irresponsible and a lame cop-out that helps us shirk our own ongoing responsibilities to strive for social justice alongside our youth allies. I'd be interested in your perspective on this issue from a young activist's viewpoint.

Rachel: I found the co-written article you shared to be very interesting and pertinent. It touches on a lot of what I have been thinking about lately, as I reflect on the work we did. You wrote: "I feel that my colleagues and I, albeit with the most honorable of intentions, often engage in rather unjust actions ourselves with the relentless seeking and promoting of youth leaders in this field” (Lund \& Paul, 2011, p. 255). What a wise observation. It made me wonder: When we engage young people in activist pursuits, are we providing them with an opportunity to use their creativity and energy to build a better world? Or are we simply trying to mould them into miniature versions of ourselves? Or, as your colleague Jim Paul put it, are we "normalizing” them (p. 257) into an adultdefined world? And in doing this, are we cheating ourselves out of the creative energy and fresh perspectives that we claim to value so much in young people? These are important questions that came up at the conference for me and that I hope I can keep in mind as I continue to work with young activists.

Darren: Your comments on these critiques and questions surrounding the problematic engagement of youth in social justice activism really remind me that forging a mutually constructive relationship with youth collaborators is such a difficult thing for many adults to do, especially for educators who are often put in the role of organizing everything. We need to follow a set curriculum in all our teaching, and to have clear learning objectives for our students, straightforward and predictable learning outcomes, and fair assessment strategies at all stages of our instruction. So being put in the role of staff advisor to a program or club that must retain some flexibility in its structure and planning is really new and often uncomfortable territory for most teachers. One principal told me, while we were watching students dance in the mosh pit at a school-based allages benefit concert that our STOP group had organized, that he felt like he was driving a full school bus downhill with no brakes! It takes a significant degree of trust, and perhaps ability to tolerate risk and failure, to allow young people to lead, and perhaps to fail. 
International Journal of Child, Youth and Family Studies (2013) 3.1: 433-443

Thinking back on the Gay-Straight Alliance, and the Students and Teachers Opposing Prejudice group that had been running since early 1987, we had many marginally successful or even disastrous events and activities, but we also had some dramatically impactful moments over the years. Our first public event with the GSA was to create eye-catching posters with pro-diversity mottos. I remember some typical ones such as, "Closets are for clothes," and some funny ones such as, "I don’t care if you're gay, straight, or Australian” with a drawing of a kangaroo. We had so much fun creating dozens of them, and putting them up around the school with the permission and approval of the principal (who, incidentally, did not approve my poster that said: "Stop flaunting your heterosexuality!”). For me, the failure part came when most were torn down, perhaps by a small number of students, early the same day.

Rachel: Even so, many positive things came out of the experiences we were creating within that group. We managed to put on many events that all youth were welcome to attend. I remember looking around our first meeting, which, if you recall, had a record turnout. The classroom was completely full! Most of the kids who came were identified as straight. They didn't need to be there, but they wanted to show support; they wanted to show up as allies. I witnessed many small victories in the hallways and classrooms, too. Even if many of the posters were torn down, the conversation had already started, and that was the most important thing.

For both of us it has led to opportunities for recognition and professional development. I don't keep in touch with the other youth that were involved with the GSA group we started, but I often wonder if their efforts were rewarded in the same way ours have been. This thought bothers me because there were some kids in the group who were much more marginalized than I was, just based on the fact that they were more "visible" minorities. Being of non-white racialized identities added another layer to their activism, I think they stuck their necks out further than we did in some ways. I wonder at how many academic conferences they have been invited to speak, and how many papers they have been able to add to their CVs because of it. These are issues that I don't see reflected in the literature on youth engagement, but that need further exploration. I don't say this to denigrate the work that you and I have done, but to remember that we haven't done it alone. It's something I think about.

Darren: What an important point, Rachel, and one that I'm often self-conscious about. I've long tried to be a good ally to a number of marginalized groups - in almost all of which I'm not an insider - so it is always with a great deal of unearned privilege that I undertake this role. Even knowing that and trying to account for it, I am still blind to many things and I continue to reap the benefits of my status in the dominant group categories as a white, straight, and (temporarily) able-bodied male. Of course, I'm proud of the things that our collective actions were able to accomplish, to break new ground then, so that our province now has dozens of high schools with active GSA groups.

Rachel: I didn't intend to make you feel self-conscious. I think a bit of selfawareness is important, but self-consciousness can be inhibiting. I think it's important for all of us to defend human rights, regardless of which group or category we belong to, and 
International Journal of Child, Youth and Family Studies (2013) 3.1: 433-443

this was certainly the kind of behaviour that you and Kirsten Spackman modelled in your roles as the teacher advisors in the STOP program.

For me, the most important personal success that came out of the formation of the GSA is simply that I was able to help create a safe place within a very hostile environment. That space should have existed anyway, but it didn't, so we created it. For an hour at lunch, every kid that came in the door could feel welcomed, accepted, supported, and eventually empowered. Once we had that space, what followed was the ability to discuss and plan the ways that we could stand up for human rights in the wider world. That was a very powerful feeling, and I continue to be grateful for your support in realizing it.

Darren: I feel honoured by my role as one of the adult mentors in the formation of that program, and by my continued association with you and so many other activists who have taken the courageous steps to make it happen. My ongoing research to discover new insights about collective social justice activism often focuses on this very topic, gaining an understanding of the adult-youth relationship in these projects. As Giroux (2010) reminded us, we all have much to gain from the active engagement of young people in respectful coalitions and educational endeavours that foster social justice: “A future in which democratic possibilities will flourish can become a reality only if young people are provided with the knowledge, capacities, and skills they need to function as social agents, active citizens, empowered workers, and critical thinkers” (p. 23).

I understand that there isn't one single way of making this happen, being a good adult facilitator, or finding a professional relationship that will work for each context, but I know that having respect for the agency and power of young people is somewhere near the core. It has been gratifying to extend our work through duoethnography once again, using this emerging dialogic method to continue our meaning-making around youth activism and coming to some new understandings about optimizing the role adults can play in adult-youth collaborations. This direction echoes recent findings showing that youth strongly prefer consensus-based decision-making that values differing viewpoints (Blanchet-Cohen, Manolson, \& Shaw, 2012). Thanks for initiating this conversation, and I look forward to many more as we continue our collective efforts toward making our schools and communities safe and just environments for all people. 
International Journal of Child, Youth and Family Studies (2013) 3.1: 433-443

\section{References}

Alberta Teachers' Association. (1992). Code of professional conduct. Edmonton, AB: Author.

Alberta Teachers' Association. (2012). Sexual orientation and gender identity [online resources]. Edmonton, AB: Author. Retrieved from http://www.teachers.ab.ca/For\%20Members/Professional\%20Development/Diver sity\%20and\%20Human\%20Rights/Sexual\%200rientation/Pages/Index.aspx

Blanchet-Cohen, N., Manolson, S., \& Shaw, K. (2012). Youth-led decision-making in community development grants. Youth \& Society. doi: 10.1177/0044118X12455024. Retrieved from http://yas.sagepub.com/content/early/2012/07/31/0044118X12455024.abstract

Boissoin, S. (2002, June 17). Homosexual agenda wicked [Letter to the editor]. Red Deer Advocate, p. A4.

Boyles, D. (Ed.). (2008). The corporate assault on youth: Commercialism, exploitation, and the end of innocence. New York: Peter Lang.

Freire, P. (1998). Pedagogy of freedom: Ethics, democracy, and civic courage. New York: Rowman \& Littlefield.

Giroux, H. (2003). The abandoned generation: Democracy beyond the culture of fear. New York: Palgrave Macmillan.

Giroux, H. (2010). Youth in a suspect society: Democracy or disposability? New York: Palgrave Macmillan.

Lund, D. E. (2007). Challenging homophobia in conservative Canada: Forming Alberta's first gay/straight alliance. In L. van Dijk \& B. van Driel (Eds.), Challenging homophobia: Teaching about sexual diversity (pp. 99-109). London: Trentham.

Lund, D. E. (2012). Student activism. In J. A. Banks (Ed.), Sage encyclopedia of diversity in education (pp. 2085-2087). Thousand Oaks, CA: Sage.

Lund, D. E., \& Evans, R. E. (2006). Opening a can of worms: A duo-ethnographic dialogue on gender, orientation and activism. Taboo: The Journal of Culture and Education, 10(2), 55-67.

Lund, D. E., Lee, L., Kaipainen, E., \& Bragg, B. (2012). Connecting with children and youth of immigrant families: Service-learning through a social justice education course. In Editorial Fellows Team (Eds.), Proceedings of the International Association for Research on Service-Learning and Community Engagement (IARSLCE) 12th Annual Conference. Baltimore, MD: IARSLCE. Retrieved from 
International Journal of Child, Youth and Family Studies (2013) 3.1: 433-443

http://iarslceproceedings2012.wikispaces.com/file/detail/Lund_Connecting+with+ children+and+youth_final.pdf

Lund, D. E., \& Paul, J. (2011). Off-loading self/other/world responsibilities: Confronting questionable ethics in youth engagement in critical pedagogy. In B. J. Porfilio \& C. Mallot (Eds.), Critical pedagogy in the 21st century: A new generation of scholars (pp. 251-283). Charlotte, NC: Information Age.

Nabavi, M., \& Lund, D. E. (2010). Youth and social justice: A conversation on collaborative activism. In W. Linds, L. Goulet, \& A. Sammel (Eds.), Emancipatory practices: Adult/youth engagement for social and environmental justice (pp. 3-13). Rotterdam, The Netherlands: Sense.

Norris, J., Sawyer, R. D., \& Lund, D. E. (Eds.). (2012). Duoethnography: Dialogic methods for social, health, and educational research. Walnut Creek, CA: Left Coast Press.

Slade, D. (2012, October 17). Appeal court upholds ruling in favour of 2002 antihomosexual letter. Calgary Herald. Retrieved from http://www2.canada.com/calgaryherald/news/city/story.html?id=b5d571cc-8de24147-a848-313583c978ae

SooHoo, S. (1995). Emerging student and teacher voices: A syncopated rhythm in public education. In B. Kanpol \& P. McLaren (Eds.), Critical multiculturalism:

Uncommon voices in a common struggle (pp. 217-234). Westport, CT: Bergin \& Garvey.

Zielinski, S. (2002, July 4). Gay teenager beaten: Victim fearful attackers could return. Red Deer Advocate, pp. A1-A2. 